Article

\title{
Effect of an Edible Coating Based on Chitosan and Oxidized Starch on Shelf Life of Carica papaya L., and Its Physicochemical and Antimicrobial Properties
}

\author{
Monserrat Escamilla-García ${ }^{1}$ (), María J. Rodríguez-Hernández ${ }^{1}$, \\ Hilda M. Hernández-Hernández ${ }^{2}$, Luis F. Delgado-Sánchez ${ }^{1}$, Blanca E. García-Almendárez ${ }^{1}$, \\ Aldo Amaro-Reyes ${ }^{1}$ (D) and Carlos Regalado-González ${ }^{1, * \mathbb{D}}$ \\ 1 Department of Food Research and Postgraduate Studies, C.U., Autonomous University of Querétaro, \\ Cerro de las Campanas S/N, Las Campanas, Santiago de Querétaro 76010, Mexico; \\ moneg14@hotmail.com (M.E.-G.); majose0880@gmail.com (M.J.R.-H.); \\ felipedelgado.ibt@gmail.com (L.F.D.-S.); blancag31@gmail.com (B.E.G.-A.); aldoamaro@gmail.com (A.A.-R.) \\ 2 CONACyT-Center of Research and Assistance in Technology and Design of Jalisco State (CIATEJ), \\ Av. Normalistas 800, Colonias de la Normal, Guadalajara, Jalisco 44270, Mexico; hhernandez@ciatej.mx \\ * Correspondence: carlosr@uaq.mx or regcarlos@gmail.com; Tel.: +52-442-123-8332
}

Received: 9 August 2018; Accepted: 6 September 2018; Published: 7 September 2018

\begin{abstract}
Papaya production plays an important economic role in Mexico's economy. After harvest, it continues to ripen, leading to softening, skin color changes, development of strong aroma, and microbial spoilage. The objective of this work was to apply an active coating of chitosan-starch to increase papaya shelf life and to evaluate physicochemical and antimicrobial properties of the coating. Papaya surfaces were coated with a chitosan-oxidized starch $(1: 3 w / w)$ solution and stored at room temperature $\left(25 \pm 1^{\circ} \mathrm{C}\right)$ for 15 days. Variables measured were color, titratable acidity, vitamin $\mathrm{C}, \mathrm{pH}$, soluble solids, volatile compounds by gas chromatography, texture, homogeneity by image analysis, and coating antimicrobial activity. At the end of the storage time, there were no significant differences $(p>0.05)$ between coated and uncoated papayas for $\mathrm{pH}(4.3 \pm 0.2)$, titratable acidity $(0.12 \% \pm 0.01 \%$ citric acid), and soluble solids $\left(12 \pm 0.2^{\circ} \mathrm{Bx}\right)$. Papaya firmness decreased to $10 \mathrm{~N}$ for coated and 0.5 $\mathrm{N}$ for uncoated papayas. Volatile compounds identified in uncoated papaya (acetic acid, butyric acid, ethyl acetate, ethyl butanoate) are related to fermentation. Total microbial population of coated papaya decreased after 15 days, whereas population of uncoated papaya increased. This active coating permitted longer shelf life of papaya than that of the uncoated fruit.
\end{abstract}

Keywords: Carica papaya L.; edible coatings; chitosan; starch; image analysis

\section{Introduction}

Papaya (Carica papaya L.) is a perennial plant with a rapid growth, and it provides fruits for more than twenty years [1]. Papaya is considered one of the most important fruits worldwide because of its high contents of ascorbic acid, provitamin A, calcium, and carotenoids [2]. Mexico is the third largest producer worldwide of this fruit with 951,922 $\mathrm{t}$ in 2016 [3]. It is a climacteric fruit that shows short life after harvest, and it is susceptible to fungi contamination mainly by Colletotrichum gloeosporioides responsible for anthracnose disease, which reduces its shelf life, severely depreciating the market value of the fruit [4]. Papaya maturation after harvest involves various metabolic processes; first, papaya is mature, hard and inedible, and after a few days of being harvested, the edible fruit becomes sweet, soft, and aromatic. However, an uncontrolled fruit maturation process can cause pulp softening, changes in skin and pulp color, and strong aroma development; all this is related to increased ethylene production causing postharvest losses [5]. 
Edible coatings have emerged as a new technology for safe maintenance and the improvement of quality of fresh fruits by their application immediately after harvest to reduce water loss and mechanical and microbial damage, prevent favorable volatiles losses, and delay senescence [6]. Coatings used for fruits preservation must have precisely balanced gas permeability properties for a normal exchange of $\mathrm{CO}_{2} / \mathrm{O}_{2}$, limited permeability to water vapor to inhibit the escape of moisture, antimicrobial activity, and good adhesion to product surface [7]. According to their composition, edible coatings may be classified into three groups: polysaccharides, proteins, and lipids as their major compounds. Coatings based on polysaccharides are characterized by providing a minimum moisture barrier, whereas gas barrier properties induce desirable atmosphere modification and increased shelf life without creation of severe anaerobic conditions. Polysaccharides commonly used in edible coatings are starch, dextrin, pectin, cellulose and its derivatives, chitosan, alginate, carrageenan, gellan, etc. [8].

Chitosan is a biopolymer obtained from chitin deacetylation in an alkaline medium, consisting of $\beta$-(1-4)-2-acetamido-D-glucose and $\beta$-(1-4)-2-amino-D-glucose units [9]. It is biodegradable, biocompatible, and nontoxic, and shows antimicrobial activity and good film-forming properties. Applied as a coating on fruit and vegetable surfaces, it reduces respiration rate by regulating gases permeability [10]. Starch is frequently used in edible coatings preparation due to its chemical, physical, and functional characteristics [11]. It comprises two structures, one linear (amylose) and the other branched (amylopectin), that are assembled naturally in granular form (size of $\sim 1 \mu \mathrm{m}$ to $100 \mu \mathrm{m}$ ) [12]. Amylose tends to be orientated in parallel due to its linearity, resulting in hydrogen bonds between hydroxyl groups reducing polymer affinity for water and allowing films and gels formation [11]. Other components may be added to edible coatings to extend their applications, such as antimicrobial agents, antioxidants, texture modifiers, dyes, flavorings, nutrients, spices, surfactants, emulsifiers, and plasticizers, among others [13].

Ethyl lauroyl arginate (LAE) is a generally recognized as safe (GRAS) cationic surfactant that is water soluble and provides antimicrobial activity against fungi and Gram-positive and Gram-negative bacteria, due to its cationic surfactant nature. It specifically affects the negatively charged microbial proteins of cell membranes or enzymatic systems, causing their denaturation and leading to microbial inhibition or death [14]. Nisin is a bacteriocin from Lactococcus lactis subsp. lactis considered as GRAS that is used in the food industry as a preservative and consists of unusual and distinctive amino acids post-translationally modified: lanthionine bound to a thioether, 3-methylanthionine, 2,3-didehydroalanine, and 2,3-didehydrobutirin. Gram-positive bacteria such as Mycobacterium, Staphylococcus spp., Clostridium sp., Listeria sp., and Bacillus sp. are very sensitive to this antibiotic [15]. The objective of this work was to evaluate the effect of an edible coating based on chitosan and oxidized starch on the shelf life of Carica papaya L., and the physicochemical and antimicrobial properties of the active coating.

\section{Materials and Methods}

\subsection{Materials}

Medium molecular weight chitosan from shrimp shells ( $375 \mathrm{kDa},>75 \%$ deacetylation), glycerol $(\geq 99.5 \%)$, and Tween 80 were purchased from Sigma-Aldrich (St. Louis, MO, USA); lactic acid (85\%) was obtained from Fermont (León, Mexico). Oxidized starch was supplied by Ingredion (San Juan del Río, Mexico), LAE was a gift from Lamirsa (Barcelona, Spain). Violet red bile agar, papa dextrose agar, plate count agar, and casein peptone were acquired from BD Bioxon (Distrito Federal, México). Papayas (Carica papaya L.) were harvested from Tecoman, Colima, Mexico. 


\subsection{Methods}

\subsubsection{Papaya Harvest}

One hundred papayas (C. papaya L. var. Maradol) were harvested from Tecoman, Colima, Mexico at maturation stage 1, defined as a yellow stripe near fruit apex (70\%-80\% of yellow surface) [16], and all fruits were similar in size and without any apparent physical damage.

\subsubsection{Coating Preparation}

Papaya edible coating was produced according to Escamilla-García et al. [17] with some modifications. One chitosan solution and one starch paste slurry were made in parallel. Chitosan $(1 \% \mathrm{w} / \mathrm{v})$ in lactic acid $(0.5 \% \mathrm{v} / \mathrm{v})$ was produced with constant agitation at $80{ }^{\circ} \mathrm{C}$ during $60 \mathrm{~min}$; the starch paste slurry was prepared with $3.5 \%(w / v)$ oxidized starch in distilled water heated at $90^{\circ} \mathrm{C}$ and stirred for $30 \mathrm{~min}$. Starch:chitosan preparations were mixed in 3:1 (w/w) ratio and stirred for $5 \mathrm{~min}$ at room temperature; glycerol was added as plasticizer at chitosan:glycerol ratio of 1:1 (w/w), and stirred for $10 \mathrm{~min}$. Previous experiments showed that a combination of $3.750 \mu \mathrm{g} / \mathrm{mL}$ of nisin and $0.0625 \mathrm{mg} / \mathrm{mL}$ of LAE were enough to inhibit coliforms, mesophilic bacteria, and yeasts, and thus were used as antimicrobial agents [18].

\subsubsection{Coating Application}

Papayas were immersed in distilled water for $1 \mathrm{~min}$ to eliminate solid residues and impurities, followed by $1 \mathrm{~min}$ immersion in neutral electrolyzed water (NEW) developed at the Center for Research and Technological Development in Electrochemistry of Querétaro (CIDETEQ), at a concentration of $200 \mathrm{ppm}$ total available chlorine. NEW is obtained by electrolysis of diluted $\mathrm{NaCl}$ solutions $(0.1 \%-1 \% w / v)$ without the use of a membrane separating anode and cathode. Several studies have shown that highly oxidizing chlorine species are present in NEW, mainly hypochlorous acid, hypochlorite ions, chlorine dioxide, and ozone, which provide high bactericidal activity [19-21]. Oxidizing species are rapidly reduced during treatments, and there is no need for rinsing. Water was removed by drying at room temperature. Coating was applied on papaya peel using a sterile sponge (Figure 1), and properties of coated papayas were evaluated at $0,5,10$, and 15 days of storage at room temperature. Uncoated papayas were used as control and were analyzed at the same storage times.

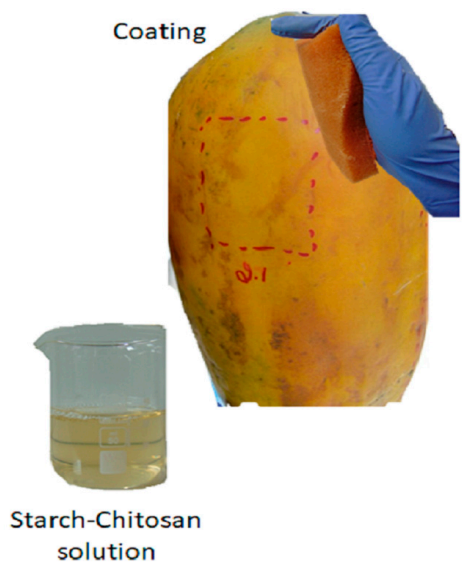

Figure 1. Coating application.

\subsubsection{Papayas Characterization}

For papaya characterization, analyses of whole papayas (without peeling) were carried out to determine volatile compounds, wt \% loss (dry basis, db), image analysis, color, and antimicrobial activity. Physicochemical parameters, such as \% acidity $(\mathrm{db})$, texture, vitamin $\mathrm{C}(\mathrm{db}), \mathrm{pH}$, and soluble solids, were determined in papaya pulp. 
Texture and Weight Loss

Texture was evaluated using a texturometer (Stable Micro Systems, TAXT2i, Surrey, UK) on papaya pulp pieces $(2 \mathrm{~cm} \times 2 \mathrm{~cm} \times 3 \mathrm{~cm})$ with and without coating. The force required to penetrate $5 \mathrm{~mm}$ of pulp was determined at $0,5,10$, and 15 days of storage. Determinations were conducted in 6 different sections of the fruit, using a $5 \mathrm{~mm}$ probe and test speed of $4 \mathrm{~mm} / \mathrm{s}$ with automatic return. Fruit weight losses, with and without coating, were recorded during storage time $(0,5,10,15$ days) using a scale (Torrey, PCR-20, Monterrey, Mexico).

$\mathrm{pH}$, Soluble Solids, Titratable Acidity, and Vitamin C

Ten $\mathrm{g}$ of papaya pulp was weighed and homogenized in $100 \mathrm{~mL}$ of distilled water, and from each sample, $3 \mathrm{pH}$ measurements were taken using a calibrated potentiometer (Hanna, Mod. 209, Woonsocket, RI, USA) at 0, 5, 10, and 15 days of fruit storage, with and without coating [22]. Soluble solids of papaya samples with and without coating were determined by an Abbe refractometer (Atago, DR-A1, Tokyo, Japan) at the different storage times. Titratable acidity was evaluated following AOAC method 942.15A, in which $5 \mathrm{~mL}$ of diluted papaya juice in $95 \mathrm{~mL}$ distilled water was titrated, with $0.1 \mathrm{M} \mathrm{NaOH}$, and expressed as citric acid percentage [23].

Color

Color changes of papaya peel surface were evaluated at the different storage times $(0,5,10$, and 15 days) with and without coating. For this test, sections in which color was determined were marked; thus, measurements were always conducted in the same section. Parameters measured were $L^{*}$ (Luminosity), $a^{*}$ (green to red), and $b^{*}$ (blue to yellow) using a Minolta CR400 colorimeter (Konica Minolta Sensing, Osaka, Japan), a light source D65, and $10^{\circ}$ angle [24].

Volatile Compounds

Volatile compounds determination was carried out according to García-Aguilar et al. [25]. Fruits were placed for $2 \mathrm{~h}$ before analysis in hermetic containers. The solid phase microextraction method was applied in this analysis using a pre-equilibrium time of $15 \mathrm{~min}$ at $50^{\circ} \mathrm{C}$. Solid-phase microextraction was performed with a $75 \mathrm{~mm}$ divinylbezene/carboxene/polydimethylsiloxane fiber (Supelco, Bellefone, VA, USA). The fiber was exposed to the interior of the hermetic containers for $20 \mathrm{~min}$ at room temperature $\left(\sim 25^{\circ} \mathrm{C}\right)$, and then placed in the injection port of a gas chromatograph (Mod. $7890 \mathrm{~A}$, Agilent Technologies, Santa Clara, CA, USA) coupled to a quadrupole mass spectrometer (Agilent, 5975C) for $45 \mathrm{~min}$ at $230^{\circ} \mathrm{C}$ for analytes desorption. Compounds identification was carried out using NIST/EPA/NIH Mass Spectra Library version 1.7 (Gaithersburg, MD, USA), considering a similarity $>80 \%$. Peak area was obtained by Equation (1):

$$
A=W_{1 / 2} h
$$

where $A$ is peak area, $W_{1 / 2}$ is width of half peak height, and $h$ is peak height.

\subsubsection{Image Analysis}

Papaya ripening changes were evaluated by image analysis (IA). Samples were illuminated using four TL-D deluxe fluorescent lamps, daylight $18 \mathrm{~W}$ (Philips, TL-D, Eindhoven, The Netherlands), and color temperature of $6500 \mathrm{~K}$ (D65). Lamps (60 cm long) were arranged in a square shape $35 \mathrm{~cm}$ above the sample at an angle of $45^{\circ}$, and pictures were taken from apical and equatorial areas of the papaya. A digital camera Nikon D3200 (Tokyo, Japan) of 24.2 Mpixels resolution was used to take images without zoom or flash, and were processed following Arzate-Vázquez et al. [26]. Using Image J 1.51j8 program [27], images were changed to 8-bit $(250 \times 250$ pixels, TIFF format $)$ and contrast, correlation, entropy, angular momentum, and fractal dimension parameters were obtained. The gray 
level co-occurrence matrix complement was used to evaluate papaya texture. Fractal dimensions (FD) were estimated by counting changes of differential boxes from gray level images.

\subsubsection{Microbiological Analysis}

Total coliforms, fungi and yeasts, and mesophilic aerobic bacteria were quantified. Papayas with and without coating at $0,5,10$, and 15 days of storage were analyzed in triplicate. Samples were prepared according to NOM-110-SSA1-1994 [28] with some modifications. Papaya weight was recorded, then the whole fruit was placed in a sterile plastic bag containing $100 \mathrm{~mL}$ of sterile peptone water $(1 \mathrm{~g}$ casein peptone, $8.5 \mathrm{~g} \mathrm{NaCl} / \mathrm{L}$, $\mathrm{pH} 7.2 \pm 0.1)$, and stirred for $3 \mathrm{~min}$ to recover the microorganisms, which were appropriately diluted to carry out population counts $(\mathrm{CFU} / \mathrm{mL})$ in triplicate experiments.

\section{Total Coliforms}

Total coliforms determination was performed by pouring $1 \mathrm{~mL}$ of each sample on violet red bile agar, using decimal dilutions where necessary, and incubated at $35^{\circ} \mathrm{C}$ for $48 \mathrm{~h}$. Red or violet colonies $(0.5 \mathrm{~mm})$ surrounded by a precipitated bile area were quantified and expressed as CFU/g [29].

Molds and Yeasts

Molds and yeasts analysis was carried out according to Pérez-Grijalva et al. [30] with some modifications. Samples of $1 \mathrm{~mL}$ were poured into potato dextrose agar $(\mathrm{pH}=3.5 \pm 0.1)$ and incubated at $25 \pm 1{ }^{\circ} \mathrm{C}$; colonies (CFU/g) were evaluated after 3 days of incubation.

Mesophilic Aerobic Bacteria

Mesophilic aerobic bacteria count was performed as described by Alsharjabi et al. [29], using plate count agar, pouring $1 \mathrm{~mL}$ of sample and incubating for $48 \mathrm{~h}$ at $37^{\circ} \mathrm{C}$. Results were reported as $\log _{10} \mathrm{CFU} / \mathrm{g}$.

\subsubsection{Statistical Analysis}

Samples were analyzed in triplicate. Data were evaluated by one-way analysis of variance (ANOVA) and significant differences were analyzed by the Tukey test $(p<0.05)$.

\section{Results and Discussion}

\subsection{Edible Coating Characterization}

\subsubsection{Texture and Weight Loss}

Firmness and weight loss changes of papaya with and without coating at different storage times are shown in Figure 2. Coated fruits required a larger force to penetrate $5 \mathrm{~mm}$ of pulp than the uncoated ones, which after 10 days of storage showed firmness loss of $92.02 \%$, whereas coated papaya showed firmness reduction of $47.36 \%$. This behavior is similar to that reported by Cortez-Vega et al. [31], who applied a fish-protein-based coating on minimally processed papaya. According to firmness values, uncoated papaya achieved its final stage of ripening after 5 days of storage (close to $10 \mathrm{~N}$ ), while coated fruit reached this stage after 15 days [4]. Figure $2 \mathrm{~b}$ shows that uncoated papaya exhibited an increasing trend in weight loss with storage time, up to $33.3 \%$ after 15 days of storage, whereas the coated fruit did not display any significant change in weight during 15 days.

Similar results were obtained by Adetunji et al. [32], who applied a layer of chitosan on papaya surface, but did find weight losses even with this coating. Hazarika et al. [33] applied coatings of carboxymethyl cellulose, chitosan, and Aloe vera on papaya, which again decreased but not suppressed weight losses. 
a)

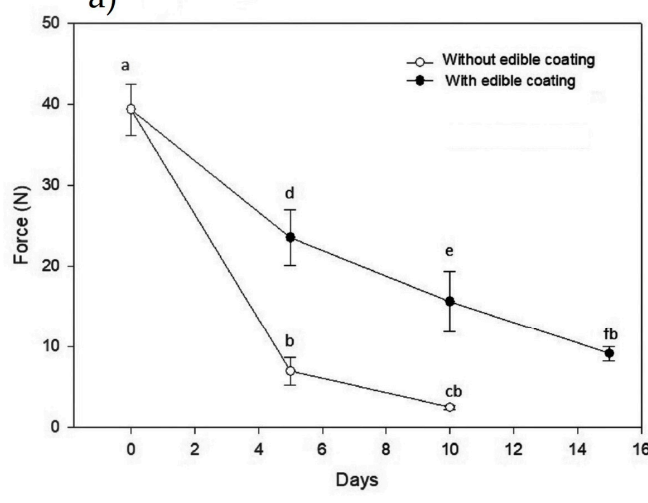

b)

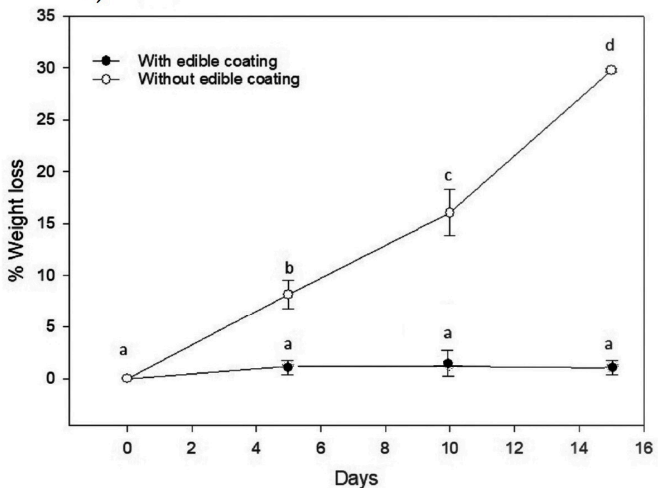

Figure 2. Physical changes during the ripening of papaya with and without coating during storage at room temperature: (a) papaya pulp firmness; (b) weight loss. a-f: used on top of reported values, indicate that if the same letter appears at different times, the values compared are not significantly different $(p>0.05)$.

\subsection{2. $\mathrm{pH}$, Soluble Solids, Titratable Acidity, and Vitamin C}

Along the storage period of papayas, the acidity showed a decreasing trend, but after 5 and 10 days, coated papaya exhibited significantly $(p<0.05)$ lower acidity than the uncoated fruits (Figure $3 a$ ). However, at the end of storage time, there was no significant difference in this parameter. A similar behavior was reported by Ali et al. [34], who applied different chitosan concentrations as coatings to papaya, and found that at least $2 \%$ chitosan $(w / v)$ was required to create an internal atmosphere to reduce acidity changes. Thus, in the present study, the applied coating did not show this feature due to similar acidity after 15 days of storage for coated and uncoated papayas.
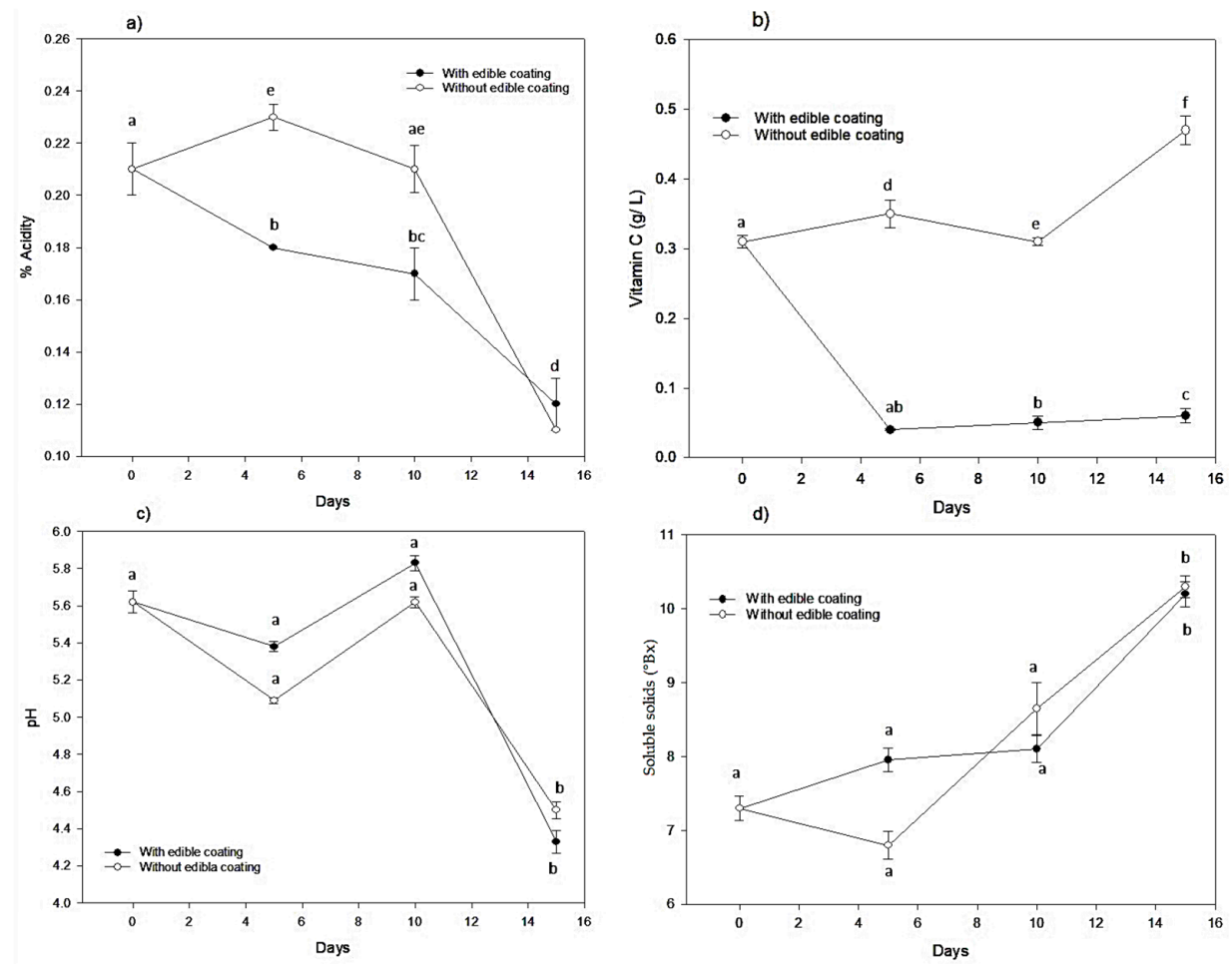

Figure 3. Chemical changes during papaya ripening, coated and uncoated, during storage time at room temperature: (a) titratable acidity (\% cítric acid); (b) vitamin $\mathrm{C}(\mathrm{g} / \mathrm{kg}) ;(\mathbf{c}) \mathrm{pH}$; (d) soluble solids. a-f: used on top of reported values, indicate that if the same letter appears at different times, the values compared are not significantly different $(p>0.05)$. 
Vitamin $C$ content is a characteristic factor in the papaya ripening process that is related to oxidative degradation during maturation stages [35]. Figure $3 \mathrm{~b}$ reveals a decrease in vitamin $\mathrm{C}$ of coated papaya after 5 days of storage, whereas the opposite was shown by the uncoated fruit, which agrees with Yurena et al. [36], who reported that vitamin C increased with maturation stage. Similar behavior was described by Wall [37] for papaya from different cultivars. Vitamin C increase may be related to increased lipid peroxidation, since this oxidative phenomenon induces intensification of antioxidant compounds such as ascorbic acid [38].

Up to 10 days of storage for both coated and uncoated papayas showed a similar trend in $\mathrm{pH}$ values, and after 15 days both treatments showed a sharp $\mathrm{pH}$ reduction significantly different from the initial value, but similar between them (Figure 3c). Reduction of $\mathrm{pH}$ during storage time was attributed to organic acids production, which is related to the papaya ripening process [31]. Soluble solids of coated and uncoated papayas did not show any significant difference $(p<0.05)$ during the storage time, increasing significantly in relation to the initial value after 15 days (Figure 3d). Jayanthunge et al. [39] obtained similar results by storing papaya in microperforated polyvinyl chloride containers, and suggested that soluble solids increased as a result of the different metabolic activities in tissues leading to pectin decomposition and carbohydrates hydrolysis into simple sugars during storage.

\subsubsection{Color}

Papaya samples color changed from mostly green to yellow-red over time (Figure 4), associated with chlorophyll degradation [5]. Uncoated papaya reached yellow-red coloration and did not reveal significant changes during the fifteen days of storage (Supplementary Figure S1), whereas coated papaya showed a gradual change from green to yellow-red as storage time increased (Figure S2). Figure $4 \mathrm{~b}$ shows chromatic change in $a^{*}$ parameter, where uncoated papaya reached a red color from day 5, without any more significant changes in the remaining storage time, while coated papaya gradually acquired this coloration.

Figure $4 \mathrm{c}$ shows significant changes for coated papaya in the $b^{*}$ chromatic value from $5-10$ days, while uncoated papaya does not show significant changes from 5 to 15 days. According to Barragán-Iglesias et al. [40], there are five papaya ripening levels based on color and days after anthesis (DAA). Physiological maturity is reached at 135 DAA and the surface is green; ripeness ready for consumption occurs at $156 \mathrm{DAA}$, and $100 \%$ of the surface is orange-red.

They defined three intermediate stages depending on the extent of orange-red color of the fruit surface: 143 DAA (25\%), 149 DAA (50\%), and 153 DAA (75\%). From the evaluated color of papaya samples, it is concluded that the application of coating delayed papaya ripening reaching maturity for consumption after 15 days, whereas uncoated papaya reached this stage after 5 days.

\subsubsection{Volatile Compounds}

The volatile compounds identified are listed in Table 1, and are in agreement with those obtained in other studies [31,41-43]. These results indicate that coating application affects the papaya ripening process. Fuggate et al. [41] and Almora et al. [44] reported papaya chemical changes during the intermediate stages of ready-for-consumption ripeness, where the amount of ethyl butanoate, ethyl hexanoate, and alcohols increased. These increments were also noted for coated and uncoated papayas, but the uncoated fruit produced ethyl butanoate after 5 days, whereas coated papaya produced it after 10 days, and its concentration after 15 days was higher in uncoated papaya. In relation to ethyl hexanoate, it was detected after 15 days of storage, with higher concentration in the uncoated papayas. 

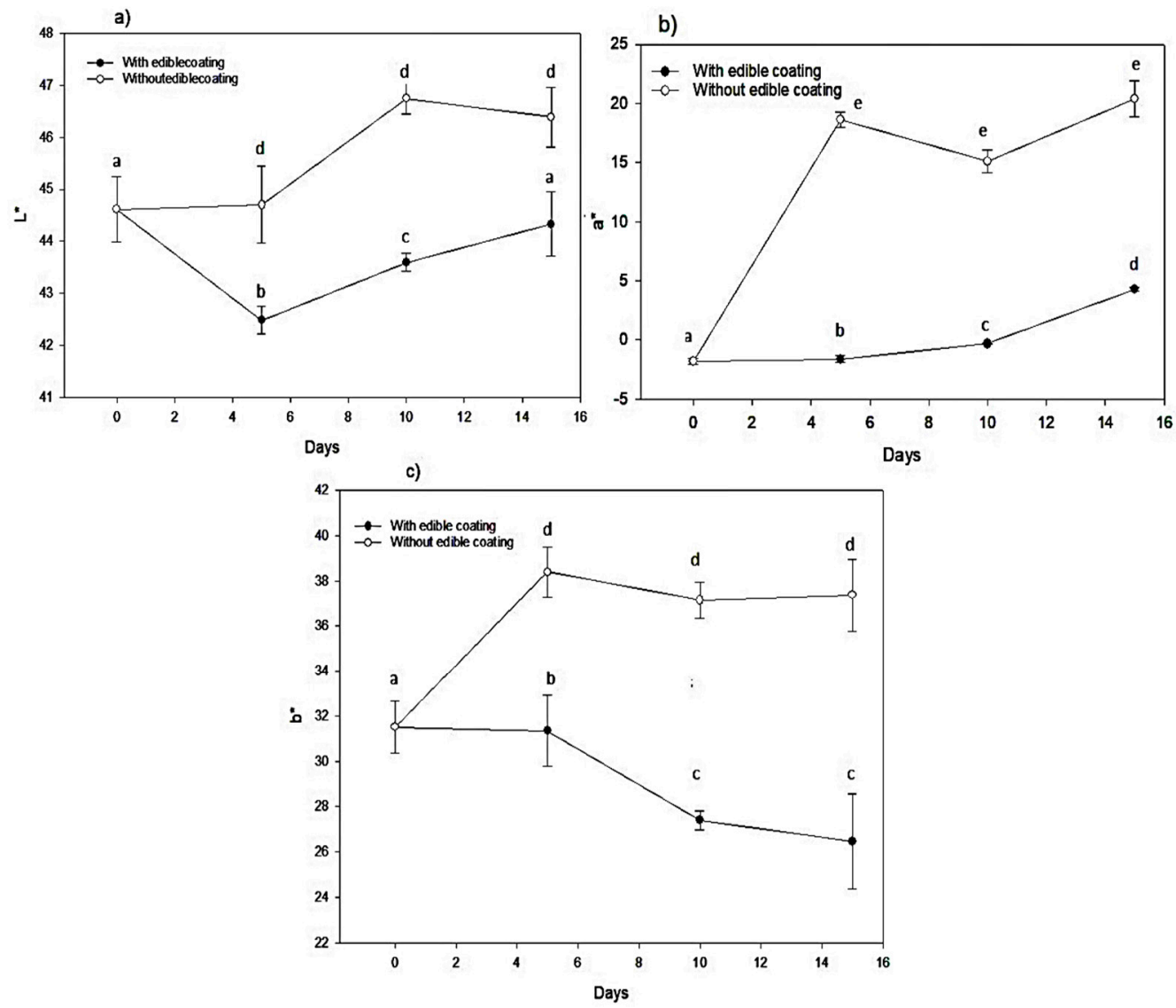

Figure 4. Papaya color changes in storage with and without edible coating: (a) $L^{*}$; (b) $a^{*}$; (c) $b^{*}$. a-d: used on top of reported values, indicate that if the same letter appears at different times, the values compared are not significantly different $(p>0.05)$.

Table 1. Volatile compounds generated during papaya ripening with and without edible coating.

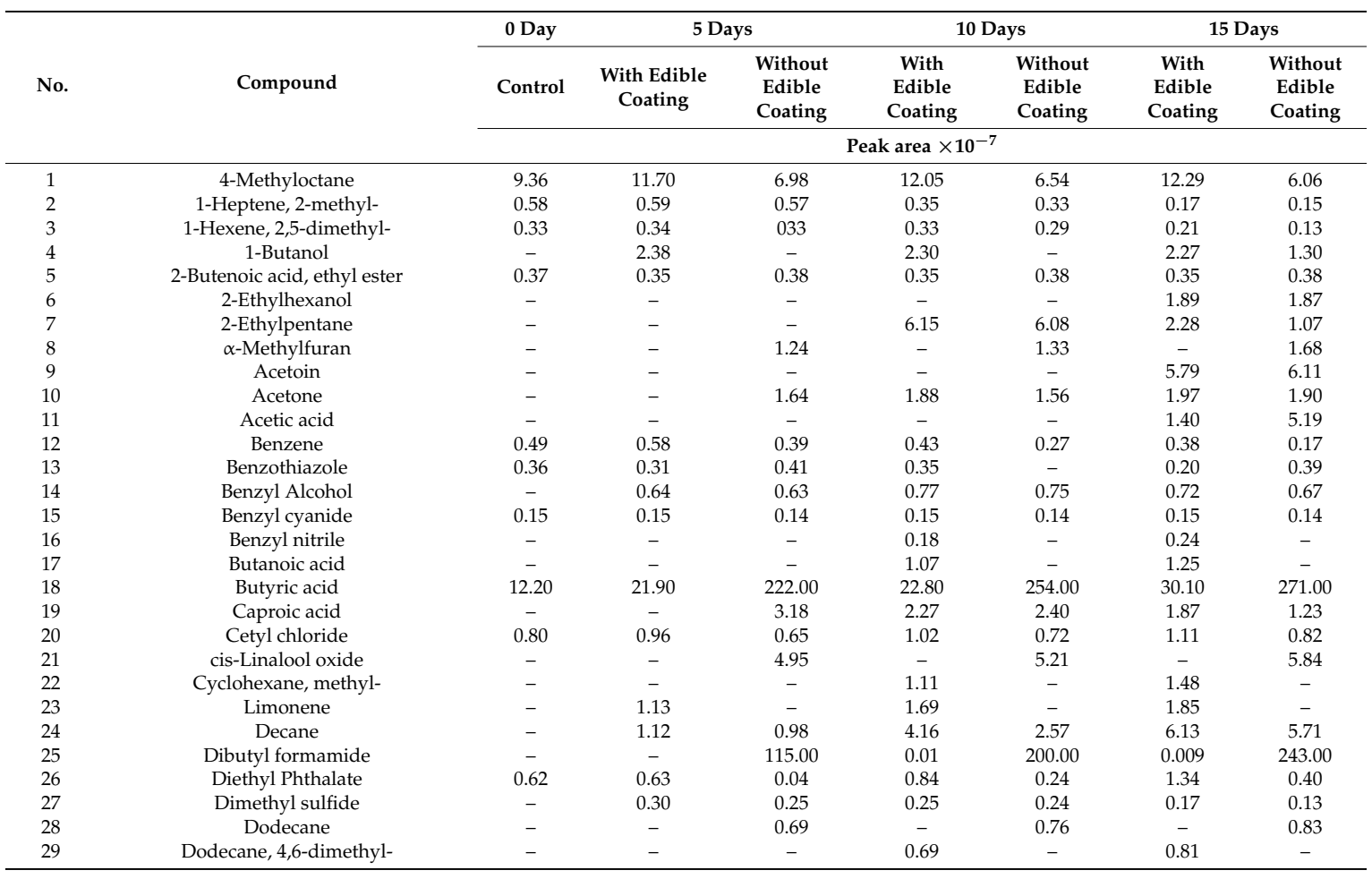


Table 1. Cont.

\begin{tabular}{|c|c|c|c|c|c|c|c|c|}
\hline \multirow[b]{2}{*}{ No. } & \multirow[b]{2}{*}{ Compound } & \multirow{2}{*}{$\begin{array}{c}\text { 0 Day } \\
\text { Control }\end{array}$} & \multicolumn{2}{|c|}{5 Days } & \multicolumn{2}{|c|}{10 Days } & \multicolumn{2}{|c|}{15 Days } \\
\hline & & & $\begin{array}{l}\text { With Edible } \\
\text { Coating }\end{array}$ & $\begin{array}{l}\text { Without } \\
\text { Edible } \\
\text { Coating }\end{array}$ & $\begin{array}{c}\text { With } \\
\text { Edible } \\
\text { Coating }\end{array}$ & $\begin{array}{l}\text { Without } \\
\text { Edible } \\
\text { Coating }\end{array}$ & $\begin{array}{c}\text { With } \\
\text { Edible } \\
\text { Coating }\end{array}$ & $\begin{array}{l}\text { Without } \\
\text { Edible } \\
\text { Coating }\end{array}$ \\
\hline 30 & Ethanol & 18.00 & 34.10 & 18.69 & 11.80 & 22.40 & 8.31 & 31.50 \\
\hline 31 & Ethyl Acetate & - & 29.10 & - & 18.70 & - & 12.90 & 6.29 \\
\hline 32 & Ethyl butanoate & - & - & 23.00 & 41.40 & 41.50 & 34.70 & 161.00 \\
\hline 35 & Formic acid, pentyl ester & - & 0.39 & - & 0.40 & - & 0.42 & - \\
\hline 36 & Heptane & 14.00 & 17.60 & 10.50 & 4.35 & 5.32 & 6.35 & 2.52 \\
\hline 37 & Hexadecane & - & - & - & 0.11 & - & 0.34 & - \\
\hline 38 & Isoheptane & - & - & 0.17 & 0.06 & 0.05 & 0.09 & 0.07 \\
\hline 39 & Isobutenylcarbinol & - & - & - & 0.06 & 2.97 & 0.09 & 0.32 \\
\hline 40 & Isopentyl alcohol, acetate & 0.83 & 0.24 & 1.42 & 0.11 & 1.84 & 0.08 & 1.95 \\
\hline 41 & Isopreno & - & - & 0.15 & - & 0.21 & - & 0.71 \\
\hline 47 & Methyl crotonate & - & - & 4.97 & - & 5.03 & - & 5.71 \\
\hline 48 & Methyl nerolate & - & - & 0.26 & - & 0.31 & - & 0.37 \\
\hline 49 & Methyl propanoate & 0.74 & 1.14 & 0.96 & 1.44 & 1.04 & 1.66 & 1.12 \\
\hline 50 & Methyl salicylate & - & - & & - & - & 0.13 & 0.17 \\
\hline 51 & Morpholine, 4-octadecyl- & - & - & 0.46 & - & 0.52 & - & 0.63 \\
\hline 52 & $N, N$-Dibutylacetamide & - & - & 0.14 & - & 0.22 & - & 0.27 \\
\hline 53 & Nonane & - & - & 0.48 & - & 0.53 & - & 0.61 \\
\hline 54 & Nonane, 2,5-dimethyl- & - & - & 4.38 & - & 4.51 & - & 4.63 \\
\hline 55 & Nonane, 2,2,4,4,6,8,8-heptamethyl- & 0.24 & 2.41 & 2.27 & 3.31 & 3.12 & 4.12 & 4.26 \\
\hline 56 & Nonane, 3-methyl-5-propyl- & - & 0.22 & - & 0.28 & - & 0.33 & - \\
\hline 57 & Octane & 1.05 & 0.25 & 0.66 & 0.30 & 0.72 & 0.39 & 0.89 \\
\hline 58 & Oxime-, methoxy-phenyl & 2.34 & 3.54 & 2.48 & 4.50 & 3.71 & 0.63 & 0.64 \\
\hline 59 & Pentadecane & - & 1.67 & - & 1.74 & - & 1.95 & - \\
\hline
\end{tabular}

Among alcohols related to papaya ripening [44] are 2-ethylhexanol and benzyl alcohol, which increased in similar quantities with storage time in coated and uncoated papayas. Ethanol was detected in both coated and uncoated papayas after 5 days, but concentration was higher in uncoated fruits at all storage times. According to Lee et al. [45], compounds such as 2-ethyl hexanol, acetic acid, butyric acid, ethyl acetate, ethyl butanoate, ethyl hexanoate, and methyl acetate are related to the papaya fermentation process. Uncoated papayas generated ethyl butanoate after 5 days, whereas coated fruits generated it after 10 days. Acetic acid appeared after 15 days in both treatments, whereas butyric acid generation was about 10 times higher in uncoated than in coated papayas (Table 1). In addition, higher amounts of these compounds were detected in uncoated papayas at all storage times. It must be pointed out that only uncoated papayas generated methyl acetate from day 5 until the end of storage time. Thus, these results indicate that coating application delays papaya fermentation.

\subsection{Microbiological Analysis}

Microbial contamination is an important cause of papaya postharvest losses. Average initial values in papaya surface were $35.3 \pm 5.5$ colony-forming units (CFU)/g of total coliforms, $548.5 \pm 97.3 \mathrm{CFU} / \mathrm{g}$ of mesophilic aerobic bacteria, $239.75 \pm 28.5 \mathrm{CFU} / \mathrm{g}$ of yeasts, and 0 molds. Figure 5 a shows total coliforms population, where a decrease is observed for the first 10 days in coated papaya, whereas population increased in uncoated papaya. A similar behavior is observed for mesophilic aerobic bacteria, where coating application allowed the reduction of $2 \log _{10} \mathrm{CFU} \mathrm{g}{ }^{-1}$ after 15 days of storage, while uncoated papaya increased their population by $2 \log _{10} \mathrm{CFU} \mathrm{g}{ }^{-1}$ (Figure 5b). Coated papaya showed a fungal population $<10 \mathrm{UFC}^{-1}$, whereas the uncoated fruits at the end of storage exhibited a population of $206 \mathrm{CFU} \mathrm{g}^{-1}$ (Figure 5c). Antimicrobial activity was most noticeable in yeasts (Figure 5d); coated papaya revealed a population decrease of $3 \log _{10} \mathrm{CFU} \mathrm{g}{ }^{-1}$ versus population increase to about 4.7 $\log _{10}$ CFU g ${ }^{-1}$ for uncoated papayas, showing a completely spoilt fruit (Figure S1d). Similar 
results have been obtained using starch-based edible coatings added with nisin and LAE, achieving inhibition against bacteria and fungi $[17,18]$.
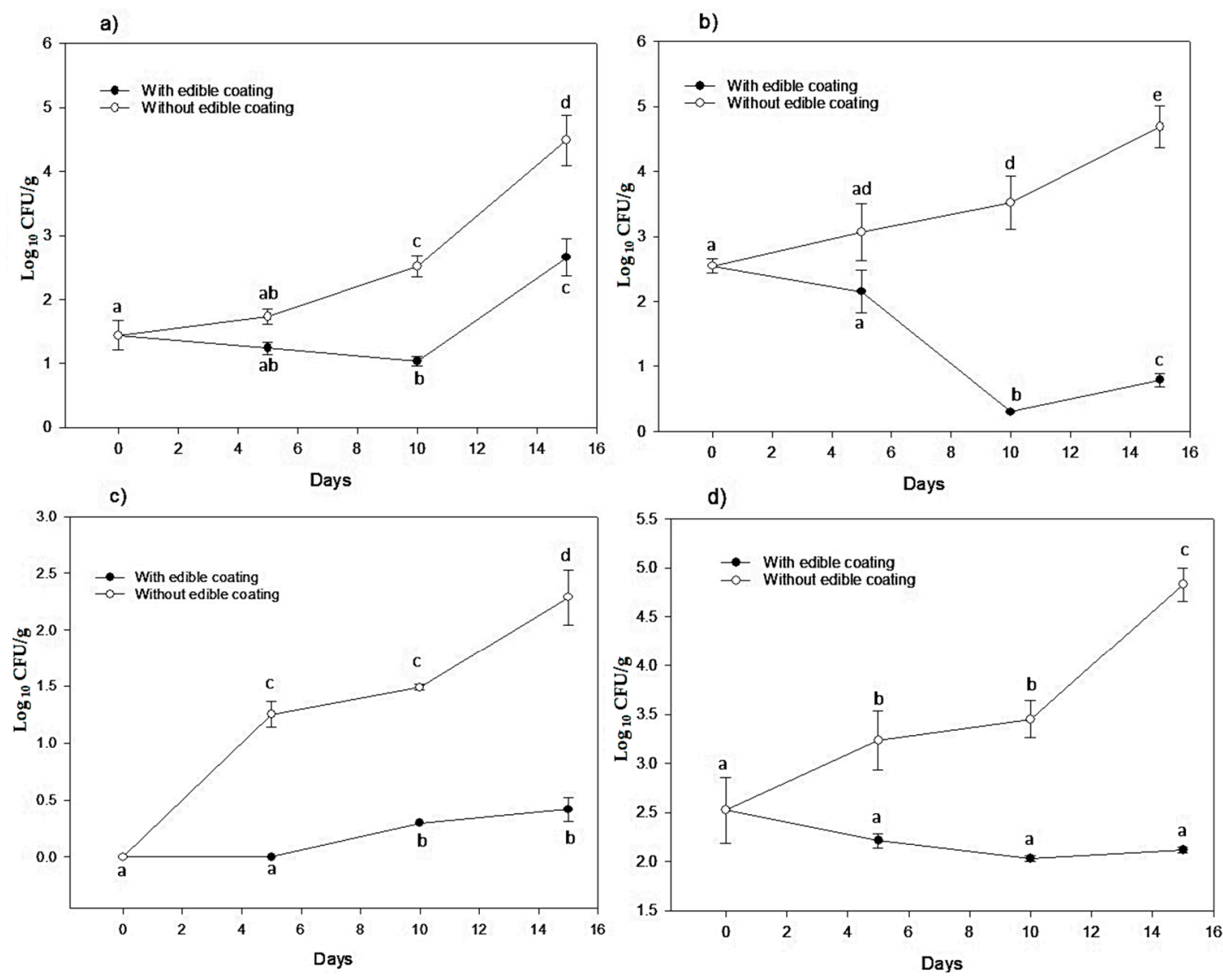

Figure 5. Antimicrobial activity of papaya with and without edible coating: (a) total coliforms; (b) mesophilic aerobic bacterial; (c) fungi; (d) yeasts. a-e: used on top of reported values, indicate that if the same letter appears at different times, the values compared are not significantly different $(p>0.05)$.

\subsection{Image Analysis}

Images showing textural changes in coated and uncoated papayas are shown in Figure 6A. Entropy is an indicator of the complexity of the texture image, and measures the disorder or randomness [46]. Entropy values decreased gradually for coated and uncoated papayas during the first days, being significantly different $(p<0.05)$ until 10 days of storage. After this time, coating application permitted lower entropy values than those of uncoated papaya, indicating a surface with less damage. Fruit texture is an important factor that can be used to determine the stage of ripening, because during this process, a detachment of parenchyma cell wall takes place [47]. These results indicate that coated papaya displays a cell membrane system more ordered and with less mobility.

The angular second moment (ASM) is a parameter that measures the homogeneity of an image [48], and ASM showed a time-dependent increment (Figure 6B). Samples with edible coating showed higher values than those without it. Images with edible coating presented higher homogeneity values due to the stage of ripening, and in uncoated papayas due to fungi present on the papayas' surface. 

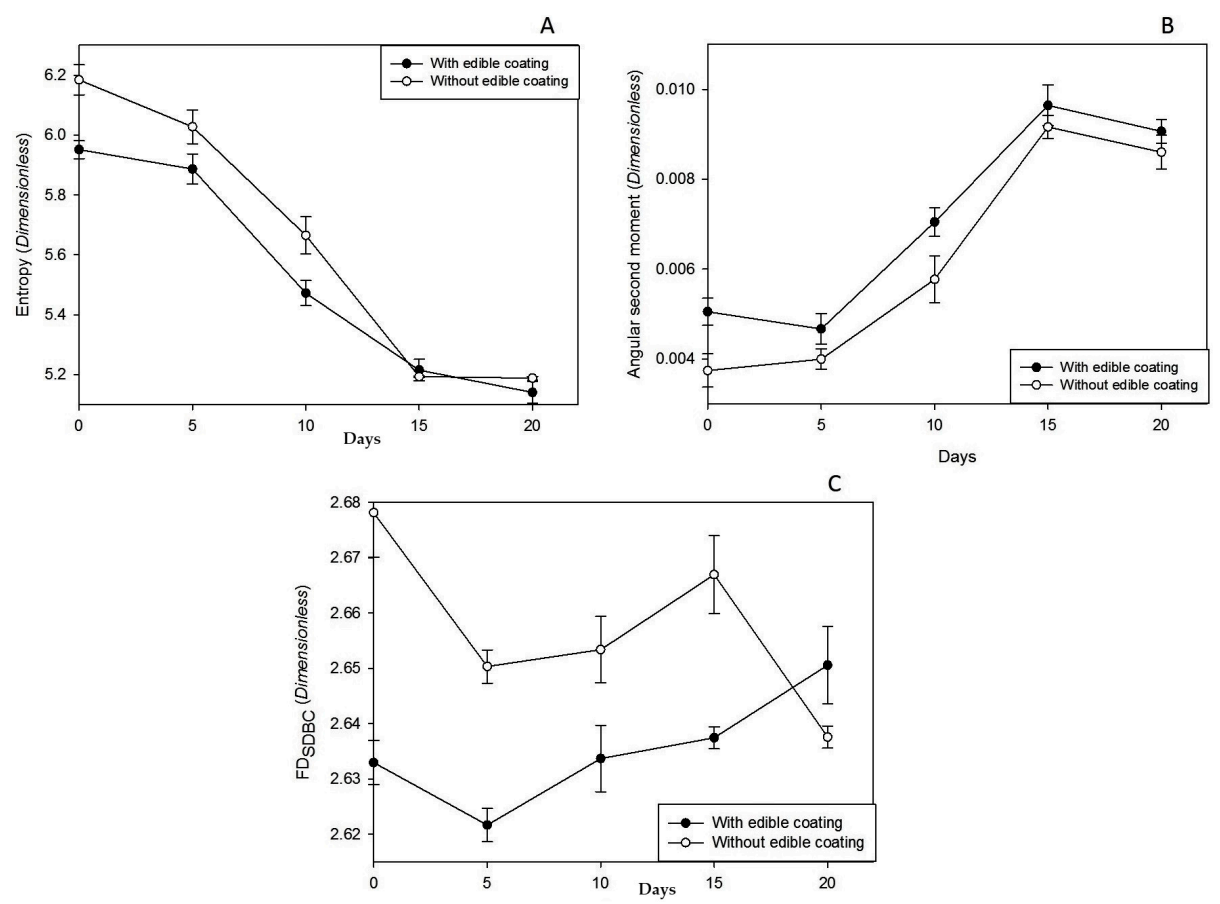

Figure 6. Image analysis of papaya with and without edible coating: (a) entropy; (b) angular second moment; (c) fractal dimension.

The fractal dimension (FD) or fractal texture is a measure of the degree of roughness of the images; the higher the values of fractal dimension, the rougher or more complex the gray level images (Figure 7), while lower FD values can be associated with simpler or smoother images. After 20 days, the FD of uncoated papaya is smaller than that of the coated fruit, and roughness was attributed to fungal growth. Samples without edible coating showed more complex images than coated papayas (Figure 6C); this could be due to changes derived from the papayas' maturation.

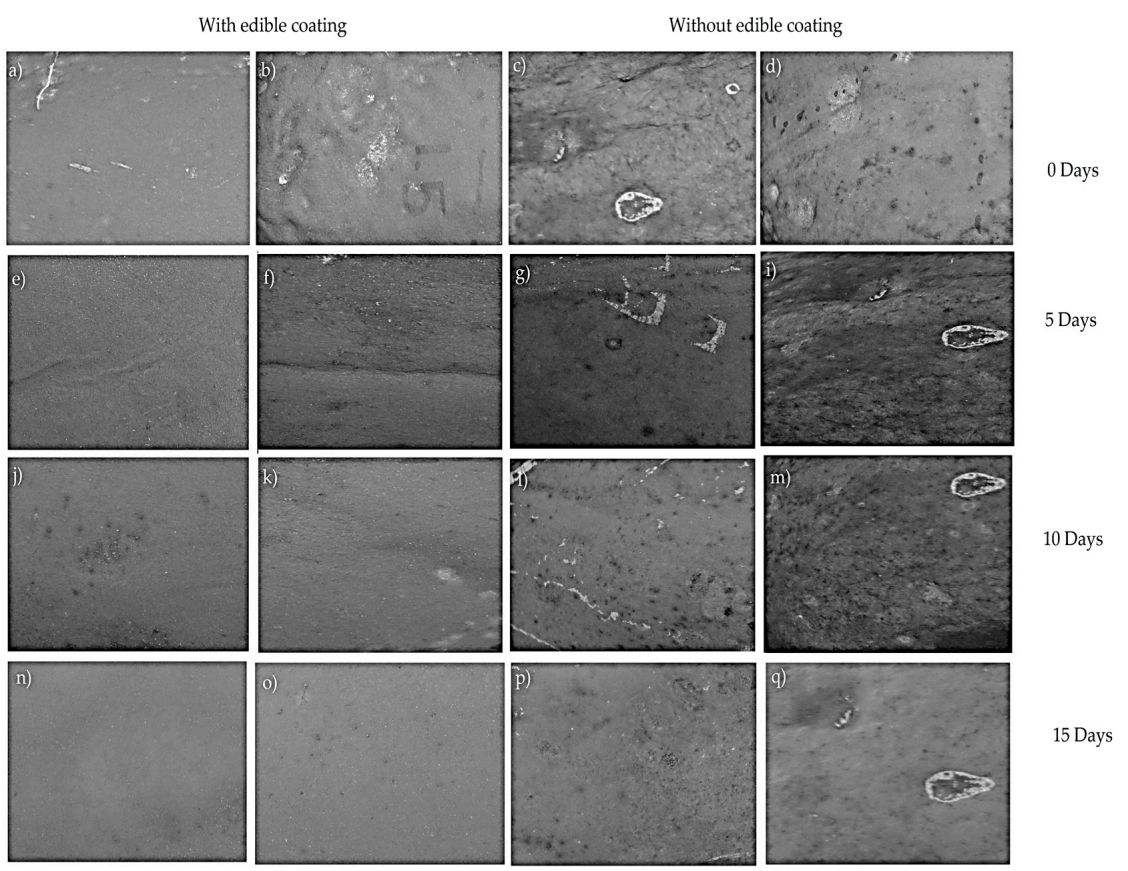

Figure 7. Grayscale papaya crops (8 bits) after different days of storage. 0 days (initial time): with coating $(\mathbf{a}, \mathbf{b})$; without coating $(\mathbf{c}, \mathbf{d}) .5$ days: with coating $(\mathbf{e}, \mathbf{f})$; without coating $(\mathbf{g}, \mathbf{i})$. 10 days: with coating $(\mathbf{j}, \mathbf{k})$; without coating $(\mathbf{l}, \mathbf{m})$. 15 days: with coating $(\mathbf{n}, \mathbf{o})$; without coating $(\mathbf{p}, \mathbf{q})$. 


\section{Conclusions}

Edible coatings exhibited a positive effect on papaya shelf life kept at room temperature, preserving its properties during a longer storage time than uncoated fruits. Coating helped to provide larger papaya pulp firmness, indicating that uncoated papaya reached a final stage of ripening after 5 days, whereas the coated fruit reached this stage after 15 days at room temperature. Volatile compounds characteristic of papaya fermentation, such as ethyl butanoate, appeared after 5 days, whereas coated fruits generated it after $10 \mathrm{~d}$. In addition, butyric acid generation was about 10 times higher in uncoated than in coated papayas throughout the 15 days of storage. Images of papaya surfaces with edible coating showed higher homogeneity values than the uncoated fruit at all storage times. Microbial population of papaya surfaces decreased during storage in the coated fruits, whereas the opposite occurred in uncoated papayas. Therefore, this coating can successfully increase papaya shelf life.

Supplementary Materials: The following are available online at http:/ /www.mdpi.com/2079-6412/8/9/318/s1, Figure S1: Color development during storage of uncoated papaya, Figure S2: Color development during storage of coated papaya.

Author Contributions: Conceptualization, M.E.-G.; Methodology, M.J.R.-H. and L.F.D.-S.; Visualization, H.M.H.-H.; Validation, B.E.G.-A. and A.A.-R.; Writing-Review \& Editing, C.R.-G.

Funding: This research was financed through the project CB-166751 from CONACyT, and AMEXCID, SRE, File B/ITA/17/001, Mexico. The publication fee was funded by Programa para el Desarrollo Profesional Docente de la Secretaría de Educación Pública of Mexico.

Acknowledgments: The authors also wish to thank the Centro de Investigación en Ciencia Aplicada y Tecnología Avanzada (CICATA) for providing the facilities for this research work and for technical assistance.

Conflicts of Interest: The authors declare no conflict of interest.

\section{References}

1. Ojo, O.A.; Ojo, A.B.; Awoyinka, O.; Ajiboye, B.O.; Oyinloye, B.E.; Osukoya, O.A.; Olayide, I.I.; Ibitayo, A. Aqueous extract of Carica papaya Linn. roots potentially attenuates arsenic induced biochemical and genotoxic effects in Wistar rats. J. Tradit. Complement. Med. 2018, 8, 324-334. [CrossRef] [PubMed]

2. Ferraz, T.M.; Rodrigues, W.P.; Netto, A.T.; de Oliveira Reis, F.; Peçanha, A.L.; de Assis Figueiredo, F.A.M.M.; de Sousa, E.F.; Glenn, D.M.; Campostrini, E. Comparison between single-leaf and whole-canopy gas exchange measurements in papaya (Carica papaya L.) plants. Sci. Hortic. 2016, 209, 73-78. [CrossRef]

3. FAOSTAT. Available online: http:/ / fenix.fao.org/faostat/internal/en/\#data/QC (accessed on 3 August 2018).

4. Zillo, R.R.; da Silva, P.P.M.; de Oliveira, J.; da Glória, E.M.; Spoto, M.H.F. Carboxymethylcellulose coating associated with essential oil can increase papaya shelf life. Sci. Hortic. 2018, 239, 70-77. [CrossRef]

5. Hamzah, H.M.; Osman, A.; Tan, C.P.; Ghazali, F.M. Carrageenan as an alternative coating for papaya (Carica papaya L. cv. Eksotika). Postharvest. Biol. Technol. 2013, 75, 142-146. [CrossRef]

6. Ncama, K.; Magwaza, L.S.; Mditshwa, A.; Tesfay, S.Z. Plant-based edible coatings for managing postharvest quality of fresh horticultural produce: A review. Food Packag. Shelf Life 2018, 16, 157-167. [CrossRef]

7. Arnon-Rips, H.; Poverenov, E. Improving food products' quality and storability by using layer by layer edible coatings. Trends Food Sci. Technol. 2018, 75, 81-92. [CrossRef]

8. Yousuf, B.; Qadri, O.S.; Srivastava, A.K. Recent developments in shelf-life extension of fresh-cut fruits and vegetables by application of different edible coatings: A review. LWT-Food Sci. Technol. 2018, 89, 198-209. [CrossRef]

9. Lima Oliveira, P.D.; de Oliveira, K.Á.R.; dos Santos Vieira, W.A.; Câmara, M.P.S.; de Souza, E.L. Control of anthracnose caused by Colletotrichum species in guava, mango and papaya using synergistic combinations of chitosan and Cymbopogon citratus (D.C. ex Nees) Stapf. essential oil. Int. J. Food Microbiol. 2018, 266, 87-94. [CrossRef] [PubMed]

10. Hajji, S.; Younes, I.; Affes, S.; Boufi, S.; Nasri, M. Optimization of the formulation of chitosan edible coatings supplemented with carotenoproteins and their use for extending strawberries postharvest life. Food Hydrocoll. 2018, 83, 375-392. [CrossRef] 
11. Guimarães, I.C.; dos Reis, K.C.; Menezes, E.G.T.; Rodrigues, A.C.; da Silva, T.F.; de Oliveira, I.R.N.; de Barros Vilas Boas, E.V. Cellulose microfibrillated suspension of carrots obtained by mechanical defibrillation and their application in edible starch films. Ind. Crops Prod. 2016, 89, 285-294. [CrossRef]

12. Zhu, F. Modifications of starch by electric field based techniques. Trends Food Sci. Technol. 2018, 75, 158-169. [CrossRef]

13. Tavassoli-Kafrani, E.; Shekarchizadeh, H.; Masoudpour-Behabadi, M. Development of edible films and coatings from alginates and carrageenans. Carbohydr. Polym. 2016, 137, 360-374. [CrossRef] [PubMed]

14. Pezo, D.; Navascués, B.; Salafranca, J.; Nerín, C. Analytical procedure for the determination of Ethyl Lauroyl Arginate (LAE) to assess the kinetics and specific migration from a new antimicrobial active food packaging. Anal. Chim. Acta 2012, 745, 92-98. [CrossRef] [PubMed]

15. Khan, I.; Oh, D.-H. Integration of nisin into nanoparticles for application in foods. Innov. Food Sci. Emerg. Technol. 2016, 34, 376-384. [CrossRef]

16. Albertini, S.; Reyes, A.E.L.; Trigo, J.M.; Sarriés, G.A.; Spoto, M.H.F. Effects of chemical treatments on fresh-cut papaya. Food Chem. 2016, 190, 1182-1189. [CrossRef] [PubMed]

17. Escamilla-García, M.; Reyes-Basurto, A.; García-Almendárez, B.E.; Hernández-Hernández, E.; Calderón-Domínguez, G.; Rossi-Márquez, G.; Regalado-González, C. Modified starch-chitosan edible films: Physicochemical and mechanical characterization. Coatings 2017, 7, 224. [CrossRef]

18. Sánchez-Ortega, I.; García-Almendárez, B.E.; Santos-López, E.M.; Reyes-González, L.R.; Regalado, C. Characterization and antimicrobial effect of starch-based edible coating suspensions. Food Hydrocoll. 2016, 52, 906-913. [CrossRef]

19. Arevalos-Sánchez, M.; Regalado, C.; Martin, S.E.; Domínguez-Domínguez, J.; García-Almendárez, B.E. Effect of neutral electrolyzed water and nisin on Listeria monocytogenes biofilms, and on listeriolysin $\mathrm{O}$ activity. Food Control 2012, 24, 116-122. [CrossRef]

20. Arevalos-Sánchez, M.; Regalado, C.; Martin, S.E.; Meas-Vong, Y.; Cadena-Moreno, E.; García-Almendárez, B.E. Effect of neutral electrolyzed water on lux-tagged Listeria monocytogenes EGDe biofilms adhered to stainless steel and visualization with destructive and non-destructive microscopy techniques. Food Control 2013, 34, 472-477. [CrossRef]

21. Rahman, S.M.E.; Khan, I.; Oh, D.H. Electrolyzed water as a novel sanitizer in the food industry: Current trends and future perspectives. Compr. Rev. Food Sci. Food Saf. 2016, 15, 471-490. [CrossRef]

22. Waghmare, R.B.; Annapure, U.S. Combined effect of chemical treatment and/or modified atmosphere packaging (MAP) on quality of fresh-cut papaya. Postharvest. Biol. Technol. 2013, 85, 147-153. [CrossRef]

23. Dhital, R.; Mora, N.B.; Watson, D.; Kohli, P.; Choudhary, R. Efficacy of limonene nano coatings on post-harvest shelf life of strawberries. LWT-Food Sci. Technol. 2018, 97, 124-134. [CrossRef]

24. Mishra, B.B.; Gautam, S.; Chander, R.; Sharma, A. Characterization of nutritional, organoleptic and functional properties of intermediate moisture shelf stable ready-to-eat Carica papaya cubes. Food Biosci. 2015, 10, 69-79. [CrossRef]

25. García-Aguilar, L.; Rojas-Molina, A.; Ibarra-Alvarado, C.; Rojas-Molina, J.I.; Vázquez-Landaverde, P.A.; Luna-Vázquez, F.J.; Zavala-Sánchez, M.A. Nutritional value and volatile compounds of black cherry (Prunus serotina) seeds. Molecules 2015, 20, 3479-3495. [CrossRef] [PubMed]

26. Arzate-Vázquez, I.; Chanona-Pérez, J.J.; de Jesus Perea-Flores, M.; Calderón-Domínguez, G.; Moreno-Armendáriz, M.A.; Calvo, H.; Godoy-Calderón, S.; Quevedo, R.; Gutiérrez-López, G. Image processing applied to classification of avocado variety Hass (Persea americana Mill.) during the ripening process. Food Bioprocess Technol. 2011, 4, 1307-1313. [CrossRef]

27. Schneider, C.A.; Rasband, W.S.; Eliceiri, K.W. NIH Image to ImageJ: 25 years of image analysis. Nat. Methods 2012, 9, 671-675. [CrossRef] [PubMed]

28. NORMA Official Mexicana NOM-110-SSA1-1994, Bienes y Servicios. Available online: http:/ / www.salud. gob.mx/unidades/cdi/nom/110ssa14.html (accessed on 28 June 2018).

29. Alsharjabi, F.A.; Al-Qadasi, A.M.; Al-Shorgani, N.K. Bacteriological evaluation of weaning dried foods consumed in Taiz City, Republic of Yemen. J. Saudi Soc. Agric. Sci. 2017, in press. [CrossRef]

30. Pérez-Grijalva, B.; Herrera-Sotero, M.; Mora-Escobedo, R.; Zebadúa-García, J.C.; Silva-Hernández, E.; Oliart-Ros, R.; Pérez-Cruz, C.; Guzmán-Gerónimo, R. Effect of microwaves and ultrasound on bioactive compounds and microbiological quality of blackberry juice. LWT-Food Sci. Technol. 2018, 87, 47-53. [CrossRef] 
31. Cortez-Vega, W.R.; Pizato, S.; de Souza, J.T.A.; Prentice, C. Using edible coatings from Whitemouth croaker (Micropogonias furnieri) protein isolate and organo-clay nanocomposite for improve the conservation properties of fresh-cut 'Formosa' papaya. Innov. Food Sci. Emerg. Technol. 2014, 22, 197-202. [CrossRef]

32. Adetunji, C.O.; Ogundare, M.O.; Ogunkunle, A.T.J.; Kolawole, O.M.; Adetunji, J.B. Effects of edible coatings from xanthum gum produced from xanthomonas campestris pammel on the shelf life of Carica papaya Linn fruits. Asian J. Agric. Biol. 2014, 2, 8-13.

33. Hazarika, T.; Lalthanpuii, M.D. Influence of edible coatings on physico-chemical characteristics and shelf-life of papaya (Carica papaya) fruits during ambient storage. Indian J. Agric. Sci. 2017, 87, 1077-1083.

34. Ali, A.; Muhammad, M.T.M.; Sijam, K.; Siddiqui, Y. Effect of chitosan coatings on the physicochemical characteristics of Eksotika II papaya (Carica papaya L.) fruit during cold storage. Food Chem. 2011, 124, 620-626. [CrossRef]

35. Siriamornpun, S.; Kaewseejan, N. Quality, bioactive compounds and antioxidant capacity of selected climacteric fruits with relation to their maturity. Sci. Hortic. 2017, 221, 33-42. [CrossRef]

36. Hernández, Y.; Lobo, M.G.; González, M. Determination of vitamin C in tropical fruits: A comparative evaluation of methods. Food Chem. 2006, 96, 654-664. [CrossRef]

37. Wall, M.M. Ascorbic acid, vitamin A, and mineral composition of banana (Musa sp.) and papaya (Carica papaya) cultivars grown in Hawaii. J. Food Compost. Anal. 2006, 19, 434-445. [CrossRef]

38. Jimenez, A.; Creissen, G.; Kular, B.; Firmin, J.; Robinson, S.; Verhoeyen, M.; Mullineaux, P. Changes in oxidative processes and components of the antioxidant system during tomato fruit ripening. Planta 2002, 214, 751-758. [CrossRef] [PubMed]

39. Jayathunge, K.G.L.R.; Gunawardhana, D.K.S.N.; Illeperuma, D.C.K.; Chandrajith, U.G.; Thilakarathne, B.M.K.S.; Fernando, M.D.; Palipane, K.B. Physico-chemical and sensory quality of fresh cut papaya (Carica papaya) packaged in micro-perforated polyvinyl chloride containers. J. Sci. Technol. 2014, 51, 3918-3925. [CrossRef] [PubMed]

40. Barragán-Iglesias, J.; Méndez-Lagunas, L.L.; Rodríguez-Ramírez, J. Ripeness indexes and physicochemical changes of papaya (Carica papaya L. cv. Maradol) during ripening on-tree. Sci. Hortic. 2018, 236, 272-278. [CrossRef]

41. Fuggate, P.; Wongs-Aree, C.; Noichinda, S.; Kanlayanarat, S. Quality and volatile attributes of attached and detached 'Pluk Mai Lie' papaya during fruit ripening. Sci. Hortic. 2010, 126, 120-129. [CrossRef]

42. Lieb, V.M.; Esquivel, P.; Castillo, E.C.; Carle, R.; Steingass, C.B. GC-MS profiling, descriptive sensory analysis, and consumer acceptance of Costa Rican papaya (Carica papaya L.) fruit purees. Food Chem. 2018, 248, 238-246. [CrossRef] [PubMed]

43. Barreto, G.P.M.; Fabi, J.P.; De Rosso, V.V.; Cordenunsi, B.R.; Lajolo, F.M.; do Nascimento, J.R.O.; Mercadante, A.Z. Influence of ethylene on carotenoid biosynthesis during papaya postharvesting ripening. J. Food Compost. Anal. 2011, 24, 620-624. [CrossRef]

44. Almora, K.; Pino, J.A.; Hernández, M.; Duarte, C.; González, J.; Roncal, E. Evaluation of volatiles from ripening papaya (Carica papaya L., var. Maradol roja). Food Chem. 2004, 86, 127-130. [CrossRef]

45. Lee, P.-R.; Ong, Y.-L.; Yu, B.; Curran, P.; Liu, S.-Q. Profile of volatile compounds during papaya juice fermentation by a mixed culture of Saccharomyces cerevisiae and Williopsis saturnus. Food Microbiol. 2010, 27, 853-861. [CrossRef] [PubMed]

46. Chang, L.; He, S.; Liu, Q.; Xiang, J.; Huang, D. Quantifying muskmelon fruit attributes with A-TEP-based model and machine vision measurement. J. Integr. Agric. 2018, 17, 1369-1379. [CrossRef]

47. Chen, A.; Yang, Z.; Zhang, N.; Zhao, S.; Chen, M. Quantitative evaluation and prediction for preservation quality of cold shocked cucumber based on entropy. Innov. Food Sci. Emerg. Technol. 2016, 35, 58-66. [CrossRef]

48. Calvo, H.; Moreno-Armendáriz, M.A.; Godoy-Calderón, S. A practical framework for automatic food products classification using computer vision and inductive characterization. Neurocomputing 2016, 175, 911-923. [CrossRef]

(C) 2018 by the authors. Licensee MDPI, Basel, Switzerland. This article is an open access article distributed under the terms and conditions of the Creative Commons Attribution (CC BY) license (http:/ / creativecommons.org/licenses/by/4.0/). 